UDK 631.147:581.524.13

Pregledni rad - Review paper

\title{
Possible uses of allelopathy in weed control in organic farming in Turkey
}

\author{
Ahmet Uludag ${ }^{1}$, İlhan Uremis ${ }^{2}$, Mine Rusen ${ }^{3}$, Nihat Tursun ${ }^{4}$ \\ ${ }^{1}$ Çanakkale Onsekiz Mart Üniversitesi, Ziraat Fakültesi Bitki Koruma Bölümü, Çanakkale \\ ${ }^{2}$ Mustafa Kemal Üniversitesi, Ziraat Fakültesi Bitki Koruma Bölümü, Hatay \\ ${ }^{3}$ Atatürk Bahçe Kültürleri Merkez Araştırma Enstitütsü, Yalova \\ 4 İnönü Üniversitesi, Ziraat Fakültesi Bahçe Bitkileri Bölümü, Malatya \\ ahuludag@yahoo.com
}

\begin{abstract}
SUMMARY
Weeds are one of the main obstacles in organic farming as well as other farming systems. In the most agricultural systems such as conventional farming, herbicides are the main tool to solve weed problems in spite of problems bearing from excess use of chemicals. Organic farmers rely on mechanical techniques which include tillage that can make soil open to erosion if it becomes only technique to be used. Allelopathy is both inhibitory and stimulatory biochemical interactions between plants. Allelopathic relations have been used to establish proper farming systems, control directly weeds and other pests, and develop chemicals less harmful to the environment. There have been researches on allelopathy in Turkey since 1980's. However, it is not easy to say that results of these studies have had a chance to be implemented. Allelopathy studies in Turkey can be integrated with organic agriculture; but, research and implementation needs elaborated.
\end{abstract} Keywords: allelopathy, weed control, organic farming.

\section{INTRODUCTION}

Weeds are one of the main constraints in agricultural production systems. It has been shown that organic fields have much more weeds (Rydberga and Milbergb, 2000) and weed management is a challenge in organic farming as well as, even more than, all other farming systems (Liebman and Davis, 2009). Many agricultural systems such as conventional agriculture rely on chiefly synthetic herbicides, which are not a tool in organic agriculture.

Various types of methods and tactics have been used to control weeds in organic agriculture. Crop rotation, cover crops, intercropping, competitive cultivars, soil amendments, cultivation, several physical tactics, good agricultural practices and biological control etc. have 
been mentioned in several literature (Liebman and Davis, 2009; Mohammadi, 2013). All these methods are aimed not only control of current weeds, but also prevention of introduction of weeds in a given field and minimizing future weed problems (Liebman and Davis, 2009). Some weed control methods are based on allelopathic relations. Allelopathy studies in Turkey have been reviewed earlier (Uludag et al., 2006; Uludag et al., 2008). However, allelopathy studies for weed control in Turkey have not been reviewed in the context of using in organic agriculture. The aim of this paper review use of allelopathy in organic agriculture and integrate allelopathy studies from Turkey with organic agriculture.

\section{ALLELOPATHY AND WEEDS}

The term of allelopathy was coined and defined by Molisch who is an Austrian scientist, although human being was aware of allelopathic relations as early as 300 B.C. (Rice, 1984). Authorities have defined allelopathy depending on their area, view or aim. The most common definition which is based on Rice's definition (Rice, 1974) is that stimulatory or inhibitory effect(s) of a plant (including microorganisms) on other plant(s) through the release of chemical compounds into the environment. Modern allelopathic research just increased after 1980 although there was some classical ecological work on allelopathy before 1970 (Dakshini et al., 1999).

It is possible to use allelopathy in weed control in different ways (Bhowmik and Inderjit, 2003; Mohammadi, 2013). However, we can divide it into two broad groups:

Natural weed management: Cover crops and plant residues produce allelopathic compounds which affect adversely germination or growth of weeds. Using crop cultivars with allelopathic properties also the other way of natural weed control. Improvement of crop varieties (either classical plant breeding or genetical engineering that is not acceptable for organic agriculture) to be used for natural weed control has been a challenge in weed science. Allelopathic interactions can be used in crop rotation. Maize-Soybean rotation both crops and/or their residues have some beneficial allelopathic effect on each other (Yang et al., 1994; Anderson and Cruse, 1995; Ri, 2012). Allelopathy in rotational crop is also suggested for weed control (Schreiber, 1992; Gozcu et al., 2006).

Natural herbicides: Allelopathic compounds could be used as natural herbicides. Some of them have been already commercialized and many of them has been showed for their allelopathic herbicidal potential (Bhowmik and Inderjit, 2003).

\section{ALLELOPATHY STUDIES ON WEEDS AND WEED MANAGAMENT IN TURKEY}

As it was mentioned above that allelopathy studies related to weeds and weed control have been reviewed before. In this review, studies published after former reviews will be focused and results will be discussed in the context of organic agriculture mainly. 
Brassica species are the most promising species that can be used in organic agriculture with different ways. The first study in Turkey was on garden radish (Raphanus sativus L.) of which effect on johnsongrass (Sorghum halepense) noticed and some preliminary experiments were done (Uygur, 1988). Uygur et al. (1990) found that garden radish extracts inhibit germination of 11 weed species, including some important species such as Sorghum halepense (L.) Pers., Alopecurus myosuroides Huds., Capsella bursa-pastoris (L.) Medik., Convolvulus arvensis L. out of 25 species studied and 4 crops (lettuce, tobacco, bean, Trifolium spp.) out of 32 crops examined. These results were highly promising use of garden radish (extracts) for weed control safely and effectively. Garden radish studies later focused on johnsongrass which is a perennial grass species and a native plant of the Mediterranean area and weed in many crops worldwide (Holm et al., 1977). Although pure extract (only pure extract; not diluted extracts up to 66\%) of johnsongrass inhibited soybean germination, there was no effect of pure extract on wheat, cotton or maize germination (Dogan, 2004), which was considered another promising result. Furthermore, he found that garden radish as a cover crop suppressed weeds and increased maize yield (Dogan, 2004). Another useful data for organic agriculture is that garden radish can be used as a rotational crop or a cover crop to control johnsongrass in cotton fields (Gozcu et al., 2006). Other Brassica species, which are round white radish (Raphanus sativus L.), black radish ( $R$. sativus L. var. niger), little radish ( $\mathrm{R}$. sativus L. var. radicula), turnip (Brassica campestris L. subsp. rapa) and rapeseed (Brassica napus L. oleifera DC.) as well as garden radish suppressed johnsongrass in field as soil mixed residues and laboratory conditions as water extracts (Uremis et al., 2009). On the contrary, some data was not much promising use of Brassica plants in some crops because aqueous extracts of little radish, turnip and thiocyanate ions on 12 different crop species proved an inhibition of germination in three crop species (maize, cucumber and barley) and of growth in barley and tomato (Topal, 1996). Residues of these species also affected germination and growth of cutleaf ground-cherry (Physalis angulata L.) (Uremis et al., 2005), which is a weed and invasive alien plant in summer crops in Turkey with Tropical American origin (Uludag and Katkat, 1991; Holm et al., 1997; Gonen, 1999). Other studies were seeking possible natural herbicidal use of allelopathic relations. Water extracts of the same six species above tested against Physalis angulata L., Amaranthus retroflexus L., Avena sterilis L., Portulaca oleracea L., Sinapis arvensis L., Solanum nigrum L. and promising results were obtained (Arslan et al., 2005; Ozdemir, 2007).

Studies with essential oils or aqueous extracts of plants to contribute natural herbicide research in Turkey have not reached a widely used product in spite of several successful studies (Uludag et al., 2006; Cetintas et al., 2006; Topal and Kocacaliskan, 2006; Kordali et al., 2007; Koloren, 2007; Salamci et al., 2007; Yıldirim, 2007; Kordali et al., 2008; Aydin and Tursun, 2010; Mutlu et al., 2010; Efil, 2012; Tazegul, 2012). Furthermore, studies on aqueous extracts and plant residues of different plants aimed mainly to explore the allelopathic potential of those species on weeds and crops (Uludag et al., 2006; Dişli, 2013). The studies with practical implication have specific importance for organic agriculture. For instance, study with plant parts of Eucalyptus camaldulensis Dehnh., Juglans regia L., Melia azederach 
L., Nerium oleander L. showed that corn yield increased comparing to weedy control while weed density was significantly reduced. However, corn yield in the hand weeded control was higher than in the allelopathic plant part treatments (Iskenderoglu, 1995). A study to find out possible rotational crop with allelopathic effect on weeds was conducted in Western Turkey. Results showed that rye and wheat were suitable as rotational because their residues affected the most important annual weed species occurring in summer crops (Portulaca oleracea L., Amaranthus retroflexus L. and Echinochloa colona (L.) Link.) while showing no toxic effects on other crop species, such as tomato, sunflower and corn (Boz, 2003).

Parasitic plants are important pests in many crops and controlling them has been challenge in agriculture. Studies to find out possible allelopathic plant species to use as natural herbicide or natural weed control tool have been conducted in Turkey. Several plant extracts and residues were researched to control broomrapes (Pheliphance and Orobanche spp.) in faba bean and tomato was promising in pot experiments; but incorporated plant parts were not effective enough in the field comparing to the pot experiment. Nevertheless, especially Lantana camara was found to be a promising allelopathic plant to control Orobanche spp. (Aksoy, 2003). Furthermore, residues of varying allelopathic plant species or exudates gave effective results on broomrapes or dodders (Cuscuta spp.) (Demirkan, 2005; Ozturk, 2006; Nemli et al., 2007; Er, 2009; Tamer, 2012).

\section{DISCUSSION}

Allelopathic studies in Turkey in the beginning were more practical purpose, although result did not have chance to be applied in wide areas. One of the reasons is herbicides were main method in conventional agriculture. The other point is problem of marketing. For instance, the demand for garden radish is limited in grocery markets, and there has not been sufficient research to improve the cropping system (Uludag et al., 2005). Other crops were studied to find out larger marketing possibility (Uremis et al., 2009) or develop different methods could be helpful (Gozcu et al., 2006). This shows that there is a gap between research and practice.

Recently, studies were conducted to find out biological herbicides. However, field data was not as successful as data in controlled environments (Aksoy, 2003). Improving products using allelopathic compounds which are mainly secondary metabolites is not easy (Bhowmik and Inderjit, 2003). Furthermore use of allelopathic relations requires knowledge on allelochemicals involved and fluctuations depending on environmental conditions and agricultural practices should be studied. For instance, fertility regimes in rye affect biomass production, tissue phytotoxicity and allelochemical content (Mwaja et al., 1995).

In spite of many studies related to alleopathic potential to use in agriculture, there has been only one study has been conducted in a field that was organic agriculture implemented (or we were able to find out in our search). Kayandan et al. (2002) researched residues of some crop species which can be considered as a cover crop on weeds in organic cotton which had been grown for four years. However, study was done only one year and the result is not good 
enough to recommend to farmers. Unfortunately, the link between research and farmers dealing with organic farming is not strong to keep up further studies and define their real problems in the fields.

\section{LITERATURE}

Aksoy, E. O.: Canavarotu türlerinin (Orobanchae spp.) Cukurova bölgesi'ndeki önemi ve mücadele olanakları üzerine araştırmalar. Cukurova Universitesi Fen Bilimleri Enstitusu Doktora Tezi, 158 p., 2003.

Anderson, I. C., Cruse, R. M.: Tillage and Allelopathic Aspects of the Corn-Soybean Rotation Effect. Allelopathy: organisms, processes, and applications Symposium, Allelopathy: organisms, processes, and applications. ACS Symposium Series, 582, 184-192, 1995.

Arslan, M., Uremis, I., Uludag, A.: Determining bio-herbicidal potential of rapeseed, radish and turnip extracts on germination inhibition of cutleaf ground-cherry (Physalis angulata L.) seeds. Journal of Agronomy, 4 (2), 134-137, 2005.

Aydin, O., Tursun, N.: Bitkisel kökenli bazı uçucu yağların bazı yabancı ot tohumlarının çimlenme ve çıkışına olan etkilerinin araştırılması. KSÜ Doğa Bilimler Dergisi, 1 (1), 11-17, 2010.

Bhowmik, $\boldsymbol{P}$., Inderjit, $C$.: Leaching of pheportunitiesvin implementing allelopathy for natural nolic compounds from leaf and needle litter of severalvweed management. Crop Protection, 22, 661-671, 2003.

Boz, O.: Allelopathic effects of wheat and rye straw on some weeds and crops. Asian Journal of Plant Sciences, 2, 772-778, 2003.

Cetintas, R., Tursun, N., Karci, A., Almira M. H., Seyithanoğlu, M.: The bio-herbicidal effects of daphne (Laurus nobilis $\mathrm{L}$.) and some of its important components on the germination of some weeds and agronomic crops. 2006 Annual International Research Conference on Methyl Bromide Alternatives and Emissions Reductions, Orlando, Florida-USA, 52, 2006.

Dakshini, K. M. M., Foy, C. L., Inderjit, C.: Allelopathy: one component in a multifaceted approach to ecology. In: Inderjit, C. L. Foy K. M. M. Dakshini (Eds.): Principles and practices in plant ecology, allelochemical interactions, CRC Press, pp. 3-14, 1999.

Demirkan, H.: Bazı bitki parçalarının Orobanche ramosa L.' nın gelisimine olan allelopatik etkilerinin arastırılması. Ege Üniversitesi Ziraat Fakültesi Dergisi, 42 (3), 45-54, 2005.

Disli, Ö.: Farklı sıcaklıkların bitki eksudatlarının ve bazı yeşil gübrelerin akhardal (Sinapis alba L.) tohum çimlenmesi ve gelişimi üzerine etkileri. Ege Üniversitesi, Fen Bilimleri Enstitüsü, Bitki Koruma Ana Bilim Dalı, Yüksek Lisans Tezi, 108 s., İzmir, 2013.

Dogan, A.: Antep turpu (Raphanus sativus L.)'nun misır bitkisine ve yabancı ot türlerine olan allelopatik etkisinin araştırılması. Cukurova Universitesi Fen Bilimleri Enstitüsü, Yüksek Lisans Tezi, 83 s., Adana, 2004.

Efil, F.: Mercanköşk (Origanum majorona L.) ve dağ kekliği (Origanum syriacum L.) uçucuyağ ve hidrosollerinin yabancı otlara karşı biyo-herbisidal potansiyellerinin belirlenmesi. Cukurova Universitesi Fen Bilimleri Enstitüsü, Yüksek Lisans Tezi, 114 s., Adana, 2012.

Er, T.: Bazı bitki ekstrak ve eksudatlarının domates' te Orobanche çimlenmesine ve gelişimine etkileriüzerine arastırmalar. Ege Üniversitesi, Fen Bilimleri Enstitüsü, Bitki Koruma Ana Bilim Dalı, Yüksek Lisans Tezi, 67 s., İzmir, 2009.

Gonen, O.: Cukurova bölgesi yazlık yabancı ot türlerinin çimlenme biyolojileri ve bilgisayar ile teşhise yönelik morfolojik karekterlerinin saptanması. Cukurova Universitesi Fen Bilimleri Enstitusu Doktora Tezi. 233 p., Adana, 1999.

Gözcü, D., Uludăg, A., Güvercin, R. S.: Antep turpunun kanyaş mücadelesinde kullanılması üzerinde bir araştırma. Allelopati Çalıştayı (13-15 Haziran 2006, Yalova) Bildiri Kitabı, 83-84, 2006.

Olm, L. G., Plucknett, D. L., Pancho, J. V., Herberger, J. P.: The world's worst weeds, distribution and biology. The University Press of Hawaii, Honolulu, 1977. 
Holm, L. G., Plucknett, D. L., Pancho, J. V., Herberger, J. P.: World weeds, natural histories and distribution. John Wiley and Sons Inc., 1997.

Iskenderoglu, S. N.: Bitki eksraktlari ve atiklarinin yabanciot turlerinin gelismesine olan biyoherbisit etkisinin arastirilmasi. Cukurova Universitesi Fen Bilimleri Enstitusu Yuksek Lisans Tezi, 121 p., Adana, 1995.

Kayandan, A., Nemli, Y., Demirci, M., Ertem, A.: Ekolojik pamuk tarımında yesil gubre olarak uygulanan bazi bitkilerin yabanciot cikisina ve pamuk verimine olan etkilerinin arastirilmasi. Türkiye Herboloji Dergisi, 5, 1-9, 2002.

Koloren, O.: Allelopathic effects of Medicago sativa L. and Vicia cracca L. leaf and root extracts on weeds. Pakistan Journal of Biological Sciences, 10 (10), 1639-1642, 2007.

Kordali, S., Cakir, A., Sutay, S.: Inhibitory effects of monoterpenes on seed germination and seedling growth. Zeitschrift für Naturforschung C, C 62c, 207-214, 2007.

Kordali, S., Cakiri, A., Ozer, H., Cakmakci, R., Kesdek, M., Mete, E.: Antifungal, phytotoxic and insecticidal properties of essential oil isolated from Turkish Origanum acutidens and three components, cavacrol, thymol and p-cymene. Bioresouarce Technology, 99, 8788-8795, 2008.

Liebman, M., Davis, A. S.: Managing weeds in organic farming systems: an ecological approach. In: Charles A. Francis (Ed.) Organic farming: the ecological system. Agronomy Monograph, 54, 2009.

Mohammadi, G. R.: Alternative weed control methods: a review. In: Soloneski, S. and M. Larramendy (Eds.) Weed and pest Control - conventional and new challenges. InTech, DOI: 10.5772/54164, 2013.

Mutlu, S., Atici, O., Esim, N.: Bioherbicidal effects of essential oils of Nepeta meyeri Benth. on weed spp. Allelopathy Journal, 26 (2), 291-300, 2010.

Mwaja, V. N., Masiunas, J. B., Weston, L. A.: Effect of fertility on biomass, phytotoxicity, and allelochemical content of cereal rye. Journal of Chemical Ecology, 21, 81-96, 1995.

Nemli, Y., Derkan, H., Uludă̆, A., Türkseven, S., Kacan, K.: Ödemis'te patateslerde sorun olan canavarotu (Orobanche spp.)' nun saptanması ve mücadelesi üzerinde arastırmalar. Ege Üniversitesi Bilimsel Arastırma Proje Kesin Raporu, 38 p., 2007.

Ozdemir, S.: Brassicaceae familyasından bazı bitkilere ait ekstraktların yabancı otlarla mücadelede biyo-herbisit olarak kullanılabilme olanaklarının araştırılması. Mustafa Kemal Universitesi Fen Bilimleri Enstitusu Yuksek Lisans Tezi, 99 p., Hatay, 2007.

Ozturk, L.: Bazı bitkilerin ve olgunlaştırma sürelerinin patateste sorun olan canavar otu (Orobanche spp.) 'na etkileri üzerinde araştırmalar. Ege Üniversitesi, Fen Bilimleri Enstitüsü, Bitki Koruma Ana Bilim Dalı, Yüksek Lisans Tezi, 70 s., İzmir, 2006.

$\boldsymbol{R} \boldsymbol{i}, \boldsymbol{S}$.: Growth promotion of maize by soybean root exudates. Legume Research, 35 (3), 226-230, 2012.

Rice, E. L.: Allelopathy. Academic Press Inc. Orlando FL., 1974.

Rice, E. L.: Allelopathy. $2^{\text {nd }}$ Edition, 422 p., Academic Press Inc. Orlando FL, 1984.

Rydberga, T., Milbergb, P.: A survey of weeds in organic farming in Sweden. Biological Agriculture and Horticulture: An International Journal for Sustainable Production Systems, 18 (2), 175-185, 2000.

Salamci, E., Kordali, S., Kotan, R., Cakir, A., Kaya, Y.: Chemical composition, antimicrobial and herbicidal effects of essential oils isolated from Turkish Tanacetum aucheranum and Tanacetum chiliophyllum var. chiliophyllum. Biochemical Systematics and Ecology, 35, 569-581, 2007.

Schreiber, M. M.: Influence of tillage, crop rotation, and weed management on giant foxtail (Setaria faberi) population dynamics and corn yield. Weed Science, 40, 645- 653, 1992.

Tamer, S. R.: Farklı sıcaklıkların, bazı yeşil gübrelerin ve bitki eksudatlarının küskütün (Cuscuta campestris (L.) Yunck.; C. approximata Bab.) çimlenmesi üzerine etkileri. Ege Üniversitesi, Fen Bilimleri Enstitüsü, Bitki Koruma Ana Bilim Dalı, Yüksek Lisans Tezi, 92 s., İzmir, 2012.

Tazegul, A. T.: Nepeta meyeri Benth. (Kedi nanesi) uçucu yağ ve ekstrelerinin herbisidal etkilerinin belirlenmesi. Ataturk Üniversitesi, Fen Bilimleri Enstitüsü, Bitki Koruma Ana Bilim Dalı, Yüksek Lisans Tezi, 54 s., Erzurum, 2012.

Topal, S.: Bazı turpgil bitki özütleri ile tiyosiyanat iyonlarının tohum çimlenmesi ve fide büyümesi üzerine allelopatik etkileri. Dumlupinar Üniversitesi, Fen Bilimleri Enstitüsü, Biyoloji Ana Bilim Dalı, Yüksek Lisans Tezi, 41 s., Kutahya, 1996. 
Topal, S., Kocacaliskan, I.: Juglonun bazı yabancı otlar ve tahıl türlerindeallelopatik etkisi. Allelopati Çalıstayı Bildiri Kitab1, 69-81, 2006.

Uludăg, A., Katkat, M.: Weeds in cotton fields and their distributions and densities in Southeast Anatolia. The Journal of Turkish Phytopathology, 20, 96, 1991.

Uludă̆, A., Uremis, I., Arslan, M., Gozcu, D.: Allelopathy studies in weed science in Turkey - a review. Journal of Plant Diseases and Protection, Sonderheft/Special Issue, XX, 419-426, 2006.

Uludă̆, A., Uremis, I., Arslan, M.: Allelopathy studies in weed science in Turkey: An update, $5^{\text {th }}$ International Weed Science Congress, Vancouver, British Columbia, Canada, 155-156, 2008.

Uludag, A., Uremis, I., Arslan, M., Gozcu, D.: Johnsongrass control using Brassiceae crops. $4^{\text {th }}$ MGPR Symposium, Turkey, 123, 2005.

Uremis, I., Arslan, D., Uludag, A., Sangun, M. K.: Allelopathic potentials of residues of six brassica species on johnsongrass (Sorghum halepense (L.) Pers. African Journal of Biotechnology, 8, 3497-3501, 2009.

Uremis, I., Arslan, M., Uludag, A.: Allelopathic effects of some brassica species on germination and growth of cutleaf ground-cherry (Physalis angulata L.) seeds. Journal of Agronomy, 5, 661-665, 2005

Uygur, F. N., Köseli, T. F., Cinar, A.: Die allelopathische wirkung von Raphanus sativus L. Zeitschrift für Pflanzenkrankheiten und Pflanzenschutz. Sonderheft, XII, 259-264, 1990.

Uygur, F. N., Köseli, T. F.: A Study on Allelopathic Effect of Radish (Raphanus sativus L.) sap on Johnsongrass (Sorghum halepense (L.) Pers.). The Journal of Turkish Phytopatology, 17, 3, 136, 1988.

Yang, C. M., Chang, A. H., Huang, C. H.: Effects of corn residues on soybean yield. Journal of Agriculture Research, China, 43, 381-390, 1994.

Yildrim, B. K.: Bazı bitkisel kökenli uçucu yağların biyoherbisidal etkilerinin araştırılması. Ondokuz Mayis Üniversitesi, Fen Bilimleri Enstitüsü, Bitki Koruma Ana Bilim Dal, Yüksek Lisans Tezi, 130 s., Samsun, 2007.

\section{Mogućnosti korišćenja alelopatije u suzbijanju korova u organskoj biljnoj proizvodnji u Turskoj}

\section{REZIME}

Korovi su jedna od važnih prepreka u organskoj proizvodnji kao i u ostlim sistemima biljne proizvodnje. U najintenzivnijem sistemu kao što je konvencionalna poljoprivreda, herbicidi su glavna alatka za reševanje problema sa korovima uprkos problemima koji se javljaju zbog njihove učestale primene. Proizvođači u organskoj proizvodnja se zaista oslanjaju na mehaničke mere koje uključuju obradu kojom zemljište činimo otvorenim i pogodnim za eroziju ukoliko se samo obrada koristi kao mera u suzbijanju korova. Alelopatske interakcije između biljaka mogu biti inhibitorne ili stimulativne. Alelopatski efekti se mogu koristiti u uspostavljanju odgovarajuće poljoprivredne proizvodnje, u direktnom suzbijanju (kontroli) korova i drugih štetnih organizama, kao i razvoju hemikalija koje se mogu koristiti u njihovom suzbijanju a manje su štetne za životnu sredinu. Alelopatska istraživanja su započeta u Turskoj još 1980-ih godina. Međutim, još uvek se ne može govoriti o mogućnostima realne primene alelopatije u suzbijanju korova. Alelopatska istraživanja u Turskoj se mogu integrisati sa organskom poljoprivredom, ali, istraživanja i implementaciju je potrebno razraditi.

Ključne reči: alelopatija; suzbijanje korova, organska poljoprivreda. 